\title{
СУЧАСНИЙ ТАНЕЦЬ ЯК ЗАСІБ РОЗВИТКУ ТВОРЧОЇ ОСОБИСТОСТІ МАЙБУТНЬОГО АКТОРА
}

\author{
Гончаренко Ю. В. \\ кандидат педагогічних наук, доиент, \\ доиент кафедри акторської майстерності \\ Запорізький національний університет \\ вул. Жуковського, 66, Запоріжжя, Украӥна \\ orcid.org/0000-0003-1045-8368 \\ julanagoncharenko@gmail.com \\ Тітов Ю. В. \\ магістр \\ Запорізький національний університет \\ вул. Жуковського, 66, Запоріжжя, Украӥна \\ orcid.org/0000-0002-4733-8557 \\ yura.titow2012@gmail.com
}

\author{
Ключові слова: \\ сучасний танецьь, творча \\ особистість, студенти- \\ актори, модерн, джаз, \\ джаз-модерн, джаз-фольк, \\ сиенічний характер.
}

\begin{abstract}
У статті на основі аналізу педагогічної, психологічної та мистецтвознавчої літератури висвітлюється сутність поняття творчої особистості, розкривається зміст i основні складники творчого потенціалу особистості, що полягають у розвиненому інтелекті, здатному стимулювати особистість до самостійної творчої діяльності, накопичення досвіду, наполегливості й цілеспрямованості творчих дій та інтересів. Зазначається, що засобами сучасного танцю можна стимулювати творчий потенціал особистості майбутнього актора, тому що саме його хореографічна лексика спрямовується на вираження емоцій, почуттів і природної сутності особистості. Закладений у сучасну хореографію танцювальний текст, що грунтується на природності рухів і відчуттів, його вільний психофізичний прояв здатний спонукати до творчої дії майбутніх акторів шляхом відтворення їхнього духовного світу через сучасні рухові прояви. Відповідність хореографії та іï музичного супроводу сучасним запитам суспільства стимулюватиме у майбутніх акторів мотивацію до творчої діяльності, до створення нового хореографічного твору, а також ініціюватиме розвиток їхньої уяви та фантазії. У роботі виділяються найбільш методично розроблені та доступні для опанування майбутніми акторами напрями сучасного танцю: модерн, джаз, джаз-модерн, джазфольк. Введення у зміст навчально-виховного процесу з хореографії майбутніх акторів цих напрямів сучасного танцю 3 використанням творчих завдань на імпровізаційну дію дозволить майбутнім акторам вільно, природно, невимушено та впевнено почувати себе під час створення художнього образу героя як минулого, так і сучасного століть. Також зазначені напрями сучасного танцю сприятимуть розвитку психофізичного апарату особистості актора, гармонізуючи його внутрішні відчуття та емоції з руховими проявами, розкриваючи та наповнюючи зображувальний образ естетичною пластичністю.
\end{abstract}




\title{
MODERN DANCE AS A WAY OF DEVELOPMENT OF CREATIVE PERSONALITY OF A FUTURE ACTOR
}

\author{
Goncharenko Yu. V. \\ Candidate of Pedagogical Sciences, Associate Professor, \\ Senior Lecturer at the Acting Department \\ Zaporizhzhia National University \\ Zhukovskoho str., 66, Zaporizhzhia, Ukraine \\ orcid.org/0000-0003-1045-8368 \\ julanagoncharenko@gmail.com \\ Titov Yu. V. \\ Master \\ Zaporizhzhia National University \\ Zhukovskoho str., 66, Zaporizhzhia, Ukraine \\ orcid.org/0000-0002-4733-8557 \\ yura.titow2012@gmail.com
}

\section{Key words:}

modern dance, creative personality, students-actors, modern, jazz, jazz-modern, jazzfolk, stage character.
The article, based on the analysis of pedagogical, psychological and art literature highlights the essence of the concept of creative personality, reveals the content and main components of creative potential of the individual, consisting a developed intellect that is capable of stimulating personality to independent creative activity, experience, perseverance and purposefulness of creative actions and interests. It is noted that the way of modern dance can stimulate the creative potential of the future actor's personality, because it is his choreographic vocabulary aimed at expressing emotions, feelings and the natural essence of personality. Embedded in modern choreography dance text based on the naturalness of movements and sensations, its free psychophysical manifestation, able to encourage creative action of future actors, by reproducing their spiritual world through modern motor manifestations. In addition, the compliance of choreography and its musical accompaniment with modern demands of society will stimulate future actors to motivate creative activity, to create a new choreographic work, as well as initiate the development of their imagination and fantasy. The most methodically developed and available for mastering by future actors the directions of modern dance are: modern, jazz, jazz-modern, jazz-folk. Introduction to the content of the educational process of choreography of future actors, areas of modern dance using creative tasks for improvisational action, will allow future actors to feel free, natural, relaxed and confident in creating an artistic image of the character, both past and present centuries. Also, these areas of modern dance will promote the development of the psychophysical organ of the actor's personality, harmonizing his inner feelings and emotions with motor manifestations, revealing and filling the pictorial image with aesthetic plasticity.
Постановка проблеми. Перетворення, що відбуваються в усіх сферах діяльності сучасної України, посилюють увагу до якісної професійної підготовки акторських кадрів, яка полягає як у формуванні теоретичних знань, так і в розвитку практичних умінь і навичок майстерності актора. Важливе місце у фаховій підготовці акторів займає мистецтво хореографії, засоби якої спрямовуються не лише на фізичне вдосконалення тіла актора, а й на його духовний внутрішній світ, сповнений творчою емоційністю, чуттєвістю та натхненністю. Одним із видів хореографії, який відповідає всім тенденціям розвитку театрального мистецтва сьогодення, є сучасний танець.

Сьогодні опублікована достатня кількість наукових та мистецтвознавчих робіт, у яких розкривається сутність і особливості сучасного танцю (О. Фомкін, Н. Хольченкова, Д. Шариков та інші), 
характеризуються напрями сучасного хореографічного мистецтва (О. Верховенко, М. Демідова, О. Микулінська, О. Чаус та інші), визначаються його розвивальні та виховні можливості в процесі формування особистості людини (Д. Курніков, М. Рожко, В. Чуба та інші). У своїх попередніх дослідженнях щодо вдосконалення творчої активності майбутніх акторів засобами пластичної імпровізації ми також підкреслювали значення сучасного танцю в їхній професійній підготовці. Проте в названих роботах не розкриваються способи розвитку творчого потенціалу особистості майбутнього актора засобами саме сучасного танцю. Вважаємо за необхідне обгрунтувати потенційні можливості сучасної хореографії у формуванні творчих вмінь та навичок майбутніх акторів.

Мета статті полягає в розкритті методів сучасного танцю, спрямованих на розвиток творчої особистості майбутнього актора.

Виклад основного матеріалу. У довідковій літературі зазначається, що творчість - це діяльність людини, яка здатна продукувати нові духовні та матеріальні цінності на основі сформованих знань, умінь і навичок, що виступають важливою умовою не лише їі всебічного виховання, а й розвитку суспільства загалом [1, с. 375]. Саме проблема розвитку творчої особистості, іiі сутність, зміст і структура широко висвітлюється в численних наукових працях педагогів та психологів. Так, Н. Карпенко вважає, що творчою особистістю є людина, яка під впливом зовнішніх факторів і власної активної діяльності набула додаткові особисті мотиви, утворення та здібності, що актуалізують ii творчий потенціал і сприяють досягненню творчих результатів у певних видах діяльності [2]. О. Туриніна під творчою особистістю розуміє людину з високим рівнем знань, неодмінною потребою в здійсненні творчості та вміннями відокремлювати зайве, непотрібне й надлишкове [3]. За визначенням Л. Міщихи, творчою особистістю є людина, яка має високий рівень розвитку творчих здібностей, володіє надзвичайним творчим потенціалом, а також схильністю до творчої діяльності [4].

На основі визначених понять можемо стверджувати, що творча особистість - це людина, яка шляхом розвитку власного потенціалу, глибоких знань, умінь та навичок, а також завдяки наполегливій цілеспрямованій творчій діяльності здатна самостійно перетворювати, інтерпретувати й реалізовувати власний новий продукт.

У роботах, присвячених психології мистецтва, визначається зміст творчої особистості, який, на думку вчених, грунтується на розвиненому інтелекті, що стимулює до самостійної творчої діяльності, накопичення досвіду, наполегливості й цілеспрямованості творчих дій та інтересів. Так, на думку В. Моляко, немає людини, яка б не була схильною до творчої діяльності, тому що в кожній людині закладений творчий потенціал, який розвивається через залучення особистості до активної творчої діяльності й ініціативності, що врешті стимулює приховані здібності до виникнення нових ідей та створення нового [2].

Спираючись на вищезазначене, можемо стверджувати, що засобами сучасного танцю можна стимулювати творчий потенціал особистості майбутнього актора, бо саме його хореографічна лексика спрямовується на вираження емоцій, почуттів та природної сутності особистості. Закладений у сучасну хореографію танцювальний текст, що грунтується на природності рухів і відчуттів, його вільний психофізичний прояв здатний спонукати до творчої активності майбутніх акторів шляхом відтворення їхнього духовного світу через сучасні рухові прояви. Крім того, відповідність хореографiï та іiі музичного супроводу сучасним запитам суспільства стимулюватиме в майбутніх акторів мотивацію до творчої діяльності, до створення нової хореографії, а також ініціюватиме розвиток їхньої уяви та фантазії.

Природа акторської творчості була темою обговорення й дослідження видатних режисерів, акторів, діячів мистецтв минулого. Видатний режисер К. Станіславський у своїх мистецтвознавчих настановах наголошував, що людина народжується зі здатністю до творчої дії, яка, на його думку, є природньою потребою створювати нове [5].

У сучасних мистецтвознавчих працях, зокрема в дослідженнях Г. Максименка, зазначається, що творча особистість саме сценічного виконавця (тобто артиста сцени) має творчі характеристики, що знаходяться в його психофізичному апараті, у якому закладені природні здібності до імпровізаціï. На його думку, саме імпровізація є дієвим втіленням постійних пошуків нових джерел власних можливостей творчої особистості актора. Учений, конкретизуючи поняття творчої особистості саме артиста, наголошує на тому, що розкриття акторського творчого потенціалу потребує розвитку передовсім його психофізичного апарату шляхом методичної роботи з удосконалення природного потенціалу [6].

Особливості артистичної творчості стали також предметом наукових досліджень Л. Міщихи. Вона зазначає, що сценічна творчість актора формується за допомогою його розвиненої уяви, яка в процесі створення сценічного характеру викликає особливий особистий психічний стан, дає змогу відтворювати на сценічному майданчику характер зображуваного персонажа, його риси, емоції, почуття та дію. Проте, на думку дослідниці, уява сама по собі не може відтворити запропонований 
режисером сценічний образ, оскільки в ньому не буде цілісності, що досягається за умови пластичного, темпоритмічного, дієвого, узагальненого наповнення образу [4]. Іншими словами, пластичність і танцювальність є одними 3 основних характеристик створення сценічного персонажа.

Спираючись на дослідження педагогів і психологів $з$ досліджуваної проблеми, можемо зазначити, що основою творчої діяльності особистості $\epsilon$ механізми знань, уяви, уваги, фантазії, волі та сприйняття. Ми впевнені, що розвиток означених якостей творчої особистості майбутнього актора буде успішним у процесі опанування ним сучасної хореографічної лексики, оскільки саме отримані характерні вміння та навички 3 сучасного танцю сприятимуть розвитку вільної, естетично забарвленої, емоційно наповненої пластичності, що дозволить відтворити правдивий сценічний характер.

Формування теоретичних знань щодо природи виникнення сучасних танців, їхнього розвитку та практичного опанування, особливостей сучасного танцю та його основних видів ретельно розглянуті в наукових працях таких вітчизняних та закордонних учених, як В. Антипін, В. Нікітін, Л. Садовнікова, Д. Шаріков. Сучасний танець і його характерні особливості також досліджені в роботах Н. Хольченкової. Спираючись на ці наукові розвідки, можемо виділити найбільш методично розроблені та доступні, на наш погляд, для опанування майбутніми акторами напрями сучасного танцю: модерн, джаз, джаз-модерн, джаз-фольк.

Введення до змісту навчально-виховного процесу майбутніх акторів цих напрямів сучасного танцю з використанням творчих завдань на імпровізаційну дію дозволить їм вільно, природно, невимушено та впевнено почуватися під час створення художнього образу сучасного героя. Також зазначені напрями сучасного танцю сприятимуть розвитку психофізичного апарату особистості актора, гармонізуючи його внутрішні відчуття та емоції 3 руховими проявами, розкриваючи й наповнюючи зображуваний образ естетичною пластичністю. Імпровізаційна дія, яка $є$ необхідною умовою під час створення сучасної хореографії, своєю чергою розкриватиме природний творчий потенціал актора. Музичний супровід, що використовується для цих напрямів танцю, має особливий окрас звучання, наповнений різнобарвними сучасними ритмічними малюнками. Він формуватиме в майбутніх акторів темпоритмічні відчуття, які доповнюватимуть цілісність створюваного персонажу ролі.

Так, стиль модерн, заснований відомою танцівницею А. Дункан наприкінці XIX - початку $\mathrm{XX}$ ст., мав на меті створення сценічних образів, котрі навіюються музичними творами, саме під час його виконання при незначних знаннях лексичної мови хореографії та мінімальному використанні найпростішої танцювальної техніки. Тобто процес виконання цього танцю грунтувався на імпровізаційній творчості, яка не мала чіткої та логічної будови хореографічної композиції. Більш структурована методика виконання танцю модерн була розроблена Мартою Грем у період так званого американського центрального нового часу 20-40 роки XX ст. [7]. В основу її методики покладений принцип самовираження під час створення виконавцем хореографічного образу, який базується на техніці концентрації та дихання. Особливість їі техніки полягає в скороченні та звільненні м'язів тіла танцівника в процесі виконання жестів, статичних поз та рухів, за допомогою яких передається глибина духовного емоційного стану зображуваних персонажів.

Пізніше настанови А. Дункан та М. Грем стосовно імпровізаційної діяльності танцівника саме в процесі виконання танцю були покладені в основу створення хореографічних композицій на матеріалі танцю модерн. Сьогодні ж хореографічна підготовка та викладання танцю модерн відбуваються не лише на основі імпровізаційної діяльності, а й із використанням знань базової техніки класичного танцю, який доповнюється вільним вираженням емоцій та почуттів, що дозволяє виконавцям емоційно та на високому технічному рівні виконувати хореографічні композиції. Отже, володіння майбутніми акторами основами танцю модерн дозволить за допомогою жестів, характерних поз, специфічних рухів впливати на створення сценічного характеру в сучасних виставах.

Іншим методично розробленим і структурованим напрямом сучасної хореографії $є$ джазовий танець і такі його різновиди, як: джаз-модерн, джаз-фанк, джаз-фольк. Батьківщиною джазового танцю вважається Америка, на теренах якої відбувся синтез африканських ритмічних рухів із іi власною танцювальною культурою. Як зазначає відомий сучасний хореограф Б. Феліксдал, сутність і технічні особливості джазового танцю, започатковані в африканській культурі, полягають у його еклектичній наповненості та відображенні філософії сучасного покоління. На його думку, сучасний джазовий танець є високохудожньою театральною та соціальною формою, у якій закладені філософські погляди існування людини в сучасному світі [7]. У джазовому танці також приховані безмежні можливості для творчої дії особистості актора, а його філософська сутність забезпечує емоційність і чуттєвість рухових проявів. Отже, можемо зазначити, що засоби джазового танцю впливають на психофізичний розвиток природних творчих здібностей актора. 
Історія розвитку танцю джаз-модерн, його теоретичні основи та методика виконання ретельно розроблені та подані в мистецтвознавчих працях В. Нікітіна. Учений наголошує на об'єднанні модерн і джаз танців у 70-х роках XX ст., що сприяло появі нового напряму в сучасному хореографічному мистецтві. Окрім визначення основних технічних рухових принципів, він уперше представив структуру уроку джаз-модерн танцю, визначивши одним із ії компонентів імпровізацію, якій відводиться значне місце у формуванні психофізичного апарату виконавця [8].

Тобто використання імпровізації в джаз-модерн танці $є$ одним із проявів творчої свободи особистості актора. Це ще раз підтверджує, що розвиток у майбутніх акторів творчих здібностей до імпровізаційної діяльності дозволить їм почуватися впевнено під час змістовного наповнення сценічного характеру. Імпровізація сприяє набуттю знань створення танцювальних композицій та формуванню в майбутніх акторів фантазї, уяви, творчих умінь, якими повинна володіти творча особистість.

Аналіз вистав, створених на основі драматургії класичних і сучасних авторів, дає підстави стверджувати, що оволодіння основними рухами джазового танцю та його різновидів (джаз-модерну, джаз-фольку) дасть можливість майбутнім акторам упевненіше почуватися під час наповнення сценічного образу характерними рисами. Прикладом є вистава, поставлена в навчальному театрі Запорізького національного університету за п’єсою Лесі Українки «Лісова пісня». Отримані теоретичні та практичні знання лексичної мови сучасної хореографії, зокрема танцю джаз-фольк, а також розвинені вміння та навички імпровізаційної діяльності дозволили студентам-акторам створити яскраві, загадкові, міфічні, сповнені характерними особливостями образи вистави. Крім того, танцювальні етюди головних персонажів вистави на основі танцю джаз-фольк під відповідний музичний супровід більш повно розкривали зміст та ідейну форму вистави, зробивши iii яскравою, емоційно глибокою, передаючи іiі емоційну наповненість почуттями кохання, вірою в добро, справедливість. Це своєю чергою дозволило викликати в глядачів відчуття міфічності, загадковості та захопленості класичним драматичним дійством та сприймати його як сучасний твір, у якому відображаються філософські й соціальні проблеми сьогодення.

Висновки. Отже, формування творчої особистості майбутнього актора буде успішним, якщо в навчально-виховний процес підготовки акторських кадрів впроваджувати методи сучасної хореографії, які грунтуються на структурованих, систематизованих, методично розроблених та, найголовніше, креативно-творчих, заснованих на імпровізаційній свободі напрямах сучасного танцю. Це дозволить студенту-актору не лише створювати цілісні характеристики зображуваних персонажів ролі, а й забезпечуватиме динаміку й темпоритм вистави, що і буде метою наших подальших досліджень.

\section{Література}

1. Гончаренко С.У. Український педагогічний словник. Київ : Либідь, 1997. 375 с. Довідкове видання. URL: https://lib.iitta.gov.ua/106820/1/Гончаренко. Педагогічний словник (1).pdf.

2. Карпенко Н.A. Психологія творчості : навч. посібник. Львів : ЛьвДУВС, 2016. 156 с. URL: http://dspace.lvduvs.edu.ua/bitstream/1234567890/347/1/Карпенко психолог творчості.pdf.

3. Туриніна О.Л. Психологія творчості : навч. посіб. Київ : МАУП, 2007. 160 c. URL: http://maup.com.ua/ assets/files/lib/book/p08_52.pdf.

4. Міщиха Л.П. Психологія творчості. Навчальний посібник. Івано-Франківськ: Гостинець, 2007. 448 c. URL: http://194.44.152.155/elib/local/sk758535.pdf.

5. Станиславский К.С. Работа актера над собой. Москва : Искусство, 1991. 200 с.

6. Максименко Григорій Творча особистість та психофізичний апарат. Кіно-Teamp. 2007. № 6. URL: https://ktm.ukma.edu.ua/show_content.php?id=745

7. Feliksdal Benjamin. Introducing Modern Jazz Dance. Amsterdam: Bekebooks. 2004. 34 p. URL: https://www.academia.edu/9640459/Introducing_Modern_Jazz_Dance.

8. Никитин В.Ю. Модерн-джаз танец: Этапы развития. Метод. Техника. Москва : ИД «Один из лучших», 2004. 414 с., ил. URL: https://nmdshi.uln.muzkult.ru/media/2018/09/17/1217333830/Nikitin_V. Yu_Modern_dzhaz._Etapy_razvitiya._Metod._TeKhnika.pdf.

\section{References}

1. Goncharemko S.U. (1997) Ukrayinskyj pedahohichnyi slovnyk [Ukrainian pedagogical dictionary]. Kyiv : Lybid. 375 p. Reference edition. URL: https://lib.iitta.gov.ua/106820/1/Гончаренко. Педагогічний словник (1).pdf.

2. Karpenko N.A. (2016) Psykholohiia tvorchosti: navch. posibnyk [Psychology of creativity: a textbook]. Lviv : LvDUVS. 156 p. URL: http://dspace.lvduvs.edu.ua/bitstream/1234567890/347/1/Карпенко психолог творчості.pdf. 
3. Turynina O.L. (2007) Psykholohiia tvorchosti: navch. posib. [Psychology of creativity: a textbook]. Kyiv: MAUP. 160 p. URL: http://maup.com.ua/assets/files/lib/book/p08_52.pdf.

4. Mishchykha L.P. (2007) Psykholohiia tvorchosti. Navchalnyi posibnyk [Psychology of creativity. A textbook]. Ivano-Frankivsk : Fairing. 448 p. URL: http://194.44.152.155/elib/local/ sk758535.pdf.

5. Stanislavskij K.S. (1991) Rabota aktera nad soboj [The work of the actor on himself]. Moscow: Art. $200 \mathrm{p}$.

6. Maksymenko Hryhorii. (2007) Tvorcha osobystist ta psykhofizychnyi aparat [Creative personality and psychophysical apparatus]. Cinema-Theater. № 6. URL: https://ktm.ukma.edu.ua/show_content.php?id=745.

7. Feliksdal Benjamin. (2004) Introducing Modern Jazz Dance. Amsterdam: Bekébooks. 34 p. URL: https://www.academia.edu/9640459/Introducing_Modern_Jazz_Dance.

8. Nikitin V. YU. (2004) Modern-dzhaz tanec: Etapy razvitiya. Metod. Tekhnika [Modern-jazz dance: Development stages. Method. Technics.]. Moscow: Publishing House "One of the best". 414 p. URL: https://nmdshi.uln.muzkult.ru/media/2018/09/17/1217333830/Nikitin_V.Yu_Modern_dzhaz._Etapy_razvitiya._Metod._TeKhnika.pdf. 